\title{
Archaeological Survey of the Post-Oak Savannah Restoration Project: Gus Engeling Wildlife Management Area, Anderson County, Texas
}

Jon J. Dowling

Follow this and additional works at: https://scholarworks.sfasu.edu/ita

Part of the American Material Culture Commons, Archaeological Anthropology Commons, Environmental Studies Commons, Other American Studies Commons, Other Arts and Humanities Commons, Other History of Art, Architecture, and Archaeology Commons, and the United States History Commons

Tell us how this article helped you.

This Article is brought to you for free and open access by the Center for Regional Heritage Research at SFA ScholarWorks. It has been accepted for inclusion in Index of Texas Archaeology: Open Access Gray Literature from the Lone Star State by an authorized editor of SFA ScholarWorks. For more information, please contact cdsscholarworks@sfasu.edu. 


\section{Archaeological Survey of the Post-Oak Savannah Restoration Project: Gus Engeling Wildlife Management Area, Anderson County, Texas}

\section{Creative Commons License}

\section{(c) (1) (8)}

This work is licensed under a Creative Commons Attribution-NonCommercial 4.0 International License 


\section{Archaeological Survey of the Post-Oak Savannah Restoration Project:}

Gus Engeling Wildlife Management Area, Anderson County, Texas

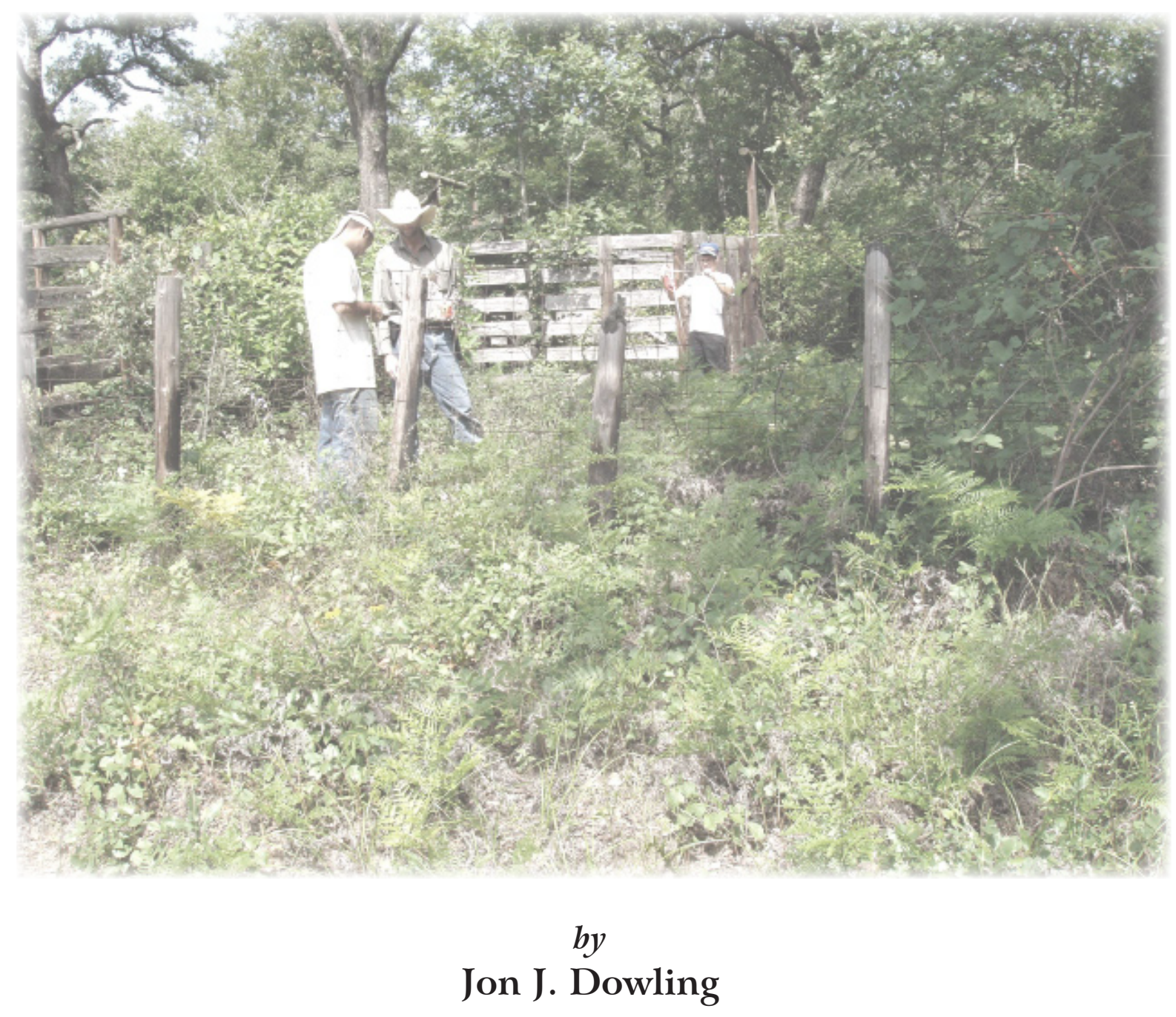

Prepared for:

Texas Parks and Wildlife Department 2400 Smith School Road Austin, Texas 78744

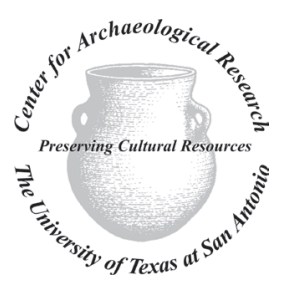

(c)2007
Prepared by:

Center for Archaeological Research The University of Texas at San Antonio Archaeological Report, No. 376 


\section{Archaeological Survey of the Post-Oak Savannah Restoration Project: Gus Engeling Wildlife Management Area, Anderson County, Texas}

by

Jon J. Dowling

Texas Antiquities Permit No. 4549

\section{Principal Investigator}

Jennifer L. Thompson

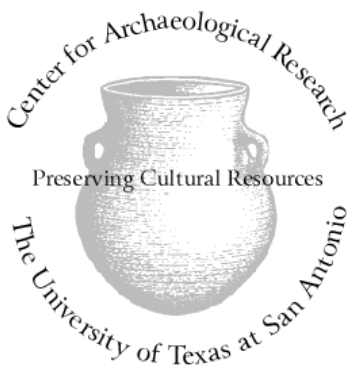

Center for Archaeological Research

The University of Texas at San Antonio

Archaeological Report, No. 376 (C)2007 


\section{Abstract}

Between May 31-June 7, 2007, personnel from UTSA's Center for Archaeological Research conducted an archaeological survey of approximately 152 acres along two boundary corridors, 17 newly proposed roads and 58 staging areas for the upcoming 2,800-acre Post-Oak Savannah Restoration Project (POSRP) at Gus Engeling Wildlife Management Area (GEWMA), Anderson County, Texas. The project area is located about four miles north of Bethel, Texas, 4.5 miles northeast of Cayuga, and about 18.5 miles northwest of Palestine, Texas. Various restoration activities are proposed to take place within specifically designated areas in the northwest quadrant of the Gus Engeling Wildlife Management Area. The project area consists of the rolling upland sand sheet of East Texas between two eastern tributaries of the Trinity River of varying archaeological potential: Mitchell Branch on the west and Catfish Creek on the east. Archaeological survey of the project area required shovel testing within designated corridors, staging areas and new roads, in addition to an intense pedestrian survey of these locations. Two hundred and ten shovel tests were excavated during the project. No cultural materials were encountered within these designated areas. A single historic corral was recorded on the project area, but was not located within areas selected for restoration activities. It is, therefore, recommended that the restoration project proceed without any additional archaeological efforts. 


\section{Table of Contents}

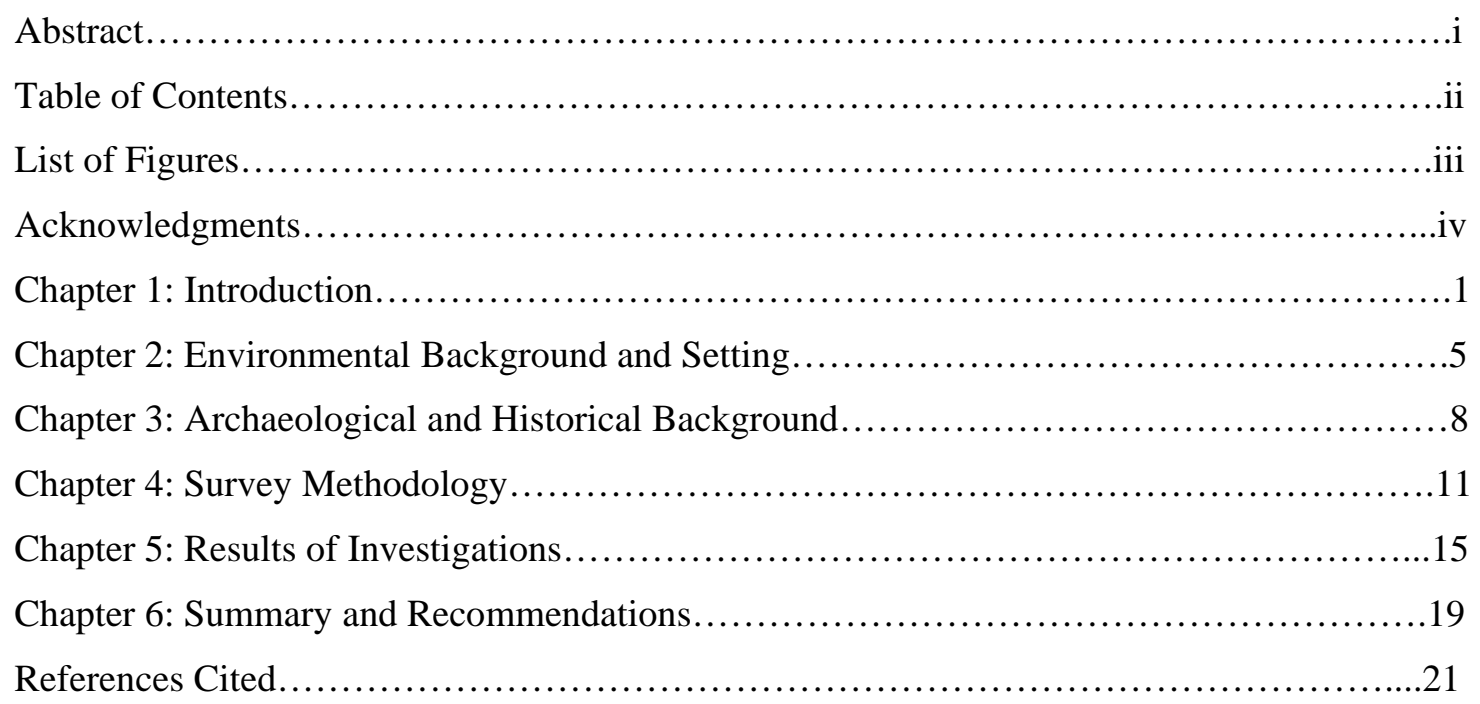




\section{List of Figures}

Figure 1-1. Anderson County, Texas..................................................

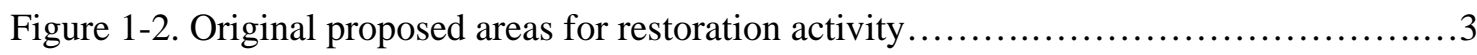

Figure 2-1. Wetland habitat in northeast portion of project area..........................6

Figure 2-2. Cut-bank revealing $120 \mathrm{~cm}$ of sandy soil above red clays......................

Figure 4-1. Project area shovel tests along N. and S. corridors, new roads 1-17, and

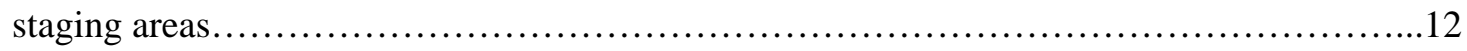

Figure 5-1. Historic corral 41AN181 location map...................................

Figure 5-2. Historic corral 41AN181 site map.....................................

Figure 5-3. CAR crew shovel testing historic corral....................................18

Figure 5-4. Historic corral fence segment.............................................18

Figure $6-1$. Texas lithic material sources..........................................19 


\section{Acknowledgements}

The author is appreciative of the assistance provided by others during this project. Chris Lintz and Wes B. Littrell of TPWD provided helpful orientating information on the project area as well as the nature of the terrain and vehicle access points. At the heart of any field endeavor is the crew, and the author is grateful for the hard work from field-techs Jason B. Perez, Nate Devito, Cyndi Dickey, Steve Dunn, Leonard Kemp, and Cathy Stacy. As always, Jim Gillentine’s 15 years of field experience proved a valuable asset on the crew. Graphics were provided by Leonard Kemp and Bruce Moses. Gratitude is extended to the P.I. Jennifer Thompson for welcomed preparation advice and groundwork, and to Bruce Moses for preliminary mapping assistance and aerial photography analysis. Useful editing insight was provided by Dr. Steve Tomka and Dr. Raymond Mauldin. 


\section{Chapter 1: Introduction}

Between May 31- June 7, 2007, staff from the Center for Archaeological Research of The University of Texas at San Antonio (UTSA) carried out an archaeological survey in selected portions of the Gus Engeling Wildlife Management Area (GEWMA) in Anderson County, Texas (Figure 1-1). The areas surveyed are projected to be the most heavily impacted activity areas associated with the 2,800 acre Post-Oak Savannah Restoration Project (POSRP) planned by the Texas Parks and Wildlife Department (TPWD) within the GEWMA. The planned POSRP will require the investigation of two corridors, indicated by aerial photographs to be in existence by 1940 and will necessitate a survey of upland settings where new roads and staging areas are to be established. The project is specifically designed not to impact drainages that are considered as high probability localities for cultural resources, and therefore, all impact areas are situated in upland settings. Nonetheless, given that the POSRP will result in ground-disturbing activities that may impact cultural resources at the GEWMA, the project falls under the stipulations of the Antiquities Code of Texas (Texas Natural Resources Code of 1977, Title 9, Chapter 191 as amended) and its attendant Rules of Practice and Procedure (Texas Administrative Code, Title 13, Part II, Chapter 26).

According to the project plans and Scope of Work provided to CAR, the planned project was to impact areas adjacent to two existing historic roads along the north and south boundaries, 17 new road segments, and 60 staging areas (Figure 1-2). The survey was conducted under Texas State Antiquities Permit \# 4549 with Jennifer Thompson serving as P.I. The goal of the survey was to locate, document and mark for avoidance possible prehistoric and historic archaeological sites within areas to be impacted by intense log preparation staging areas.

Three areas were targeted for pedestrian survey. A $20 \mathrm{~m}$ wide corridor along the northern boundary of the project area, from the southern edge of County Road 2961 running 1,800 m long, was shovel tested at $100 \mathrm{~m}$ intervals along two transects spaced roughly $5 \mathrm{~m}$ apart. Another $20 \mathrm{~m}$ wide corridor along the southern boundary of the project area, running $700 \mathrm{~m}$ long was tested in the same manner. Originally, the two corridor areas to be tested were much longer, but were greatly reduced by TPWD to avoid considerable drainage slopes and wetlands. Second, 60 staging areas where log trimming and loading activities are to take place required two shovel tests for each of the 2 acre pads. As landscape conditions affected original project proposals, 2 of the original 60 staging areas were eventually disregarded. Finally, 17 new road segments, roughly $6 \mathrm{~m}$ 


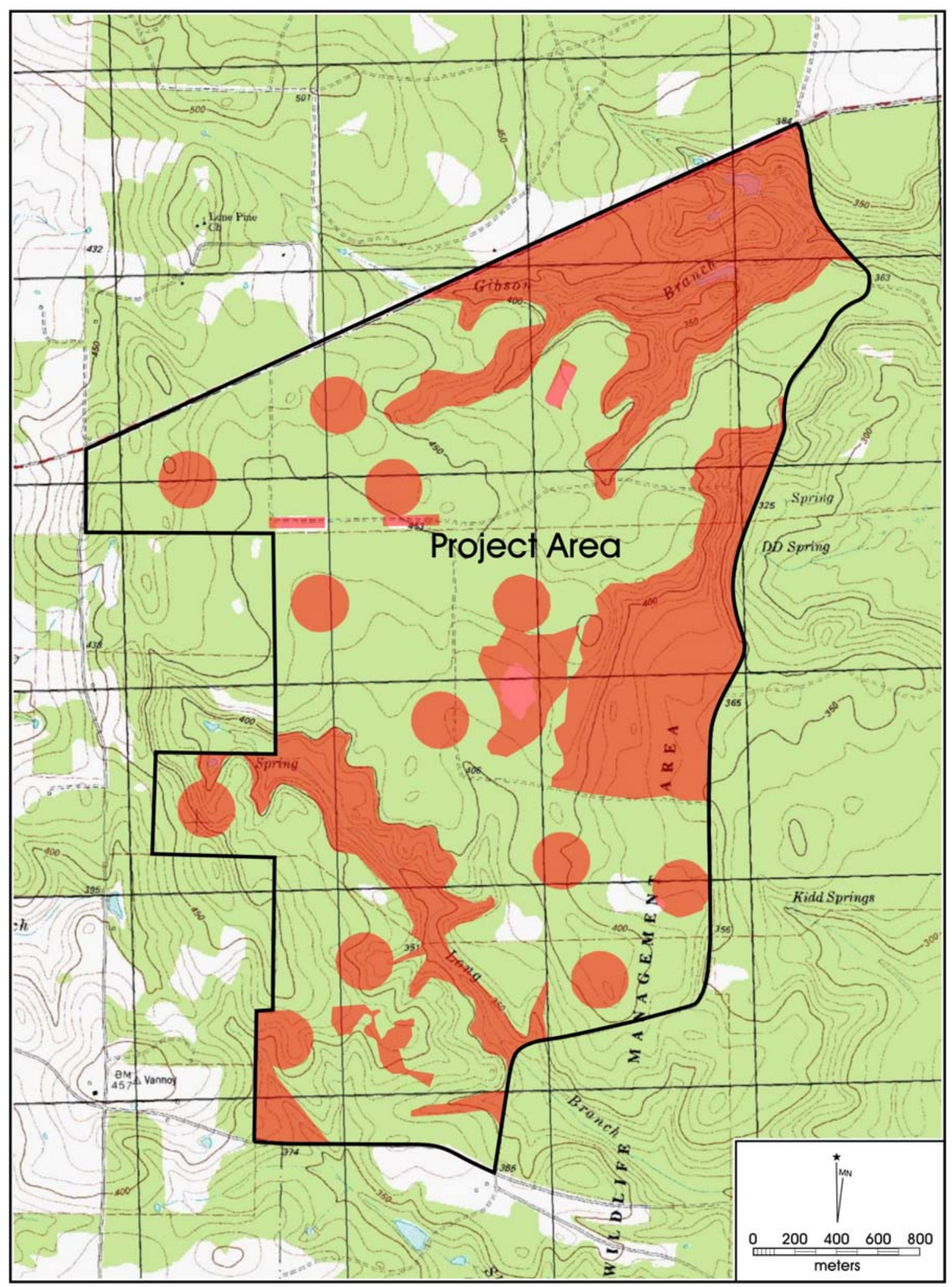

Figure 1-1. Project location and areas originally excluded from survey by TPWD due to drainages and sloping landscape. 


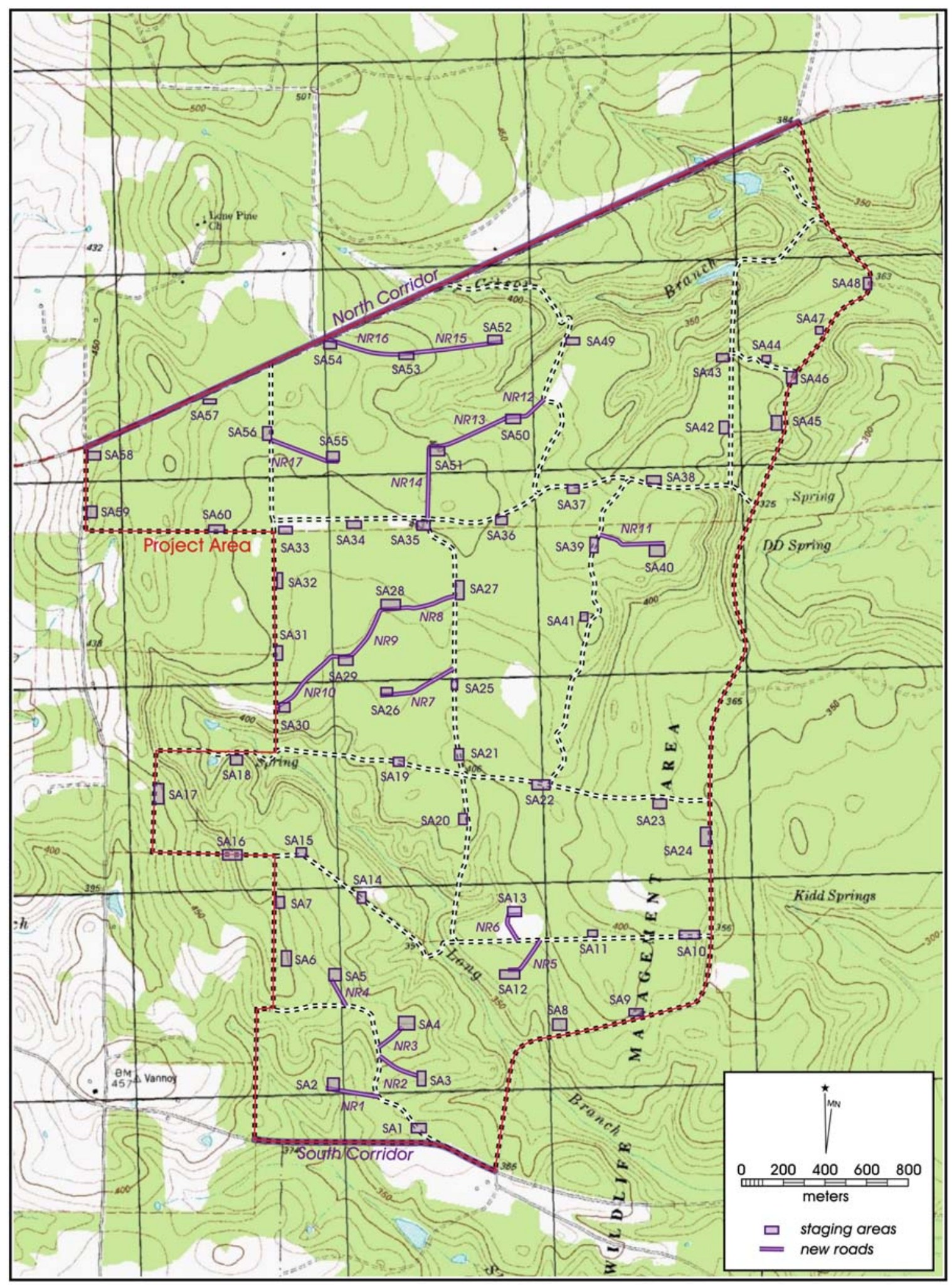

Figure 1-2. Original proposed areas for restoration activities. 
wide, that will be used to access the above mentioned staging areas, were also tested at 100 meter intervals. All targeted areas within the GEWMA were sufficiently tested, and no cultural remains were encountered. A single historic site (41AN181) was recorded, but no prehistoric materials were encountered on this survey.

This report presents the methods of investigations and conclusions of the archaeological survey of this portion of the Gus Engeling Wildlife Management Area. It is organized in consecutive chapters to be used by the Texas Parks and Wildlife Department in the development of a management plan for the northwest portion of the property. 


\section{Chapter 2: Environmental Background and Setting}

The Gus Engeling Wildlife Management Area consists of 10,958 acres of land owned and managed by the TPWD. The GEWMA is located in the northwest corner of Anderson County, 18.5 miles northwest of Palestine, Texas, U.S. Highway 287 and was purchased by TPWD in 1950 and 1951. This area was chosen for the development and management of wildlife habitats for numerous wildlife species indigenous to the Post Oak Savannah Ecological Region. It was named after a wildlife biologist who was killed by a poacher on the property in the 1950s.

The project area is characterized by gently rolling sand hills and terraces that transition into flat hardwood bottomlands. Seven spring-fed streams in the GEWMA property flow year-round. These streams drain from the upland areas down into Catfish Creek, a tributary of the Trinity River. This continual flow of water from about 8 miles of Catfish Creek is vital to the abundant wetland-dependent species (Figure 2-1). Over 35 mammals, 165 birds, 65 reptiles and amphibians, and 55 fish species reside on GEWMA (TPWD 2005). Some of the animals present on the property include white-tailed deer, squirrels, wild turkeys, feral hogs, rabbits, bobcats, beavers, raccoons, coyotes, ducks, copperhead snakes and alligators. The most commonly encountered insects during survey included large populations of mosquitoes, ticks, golden orb weaver spiders, and grasshoppers.

The climate in this region is subhumid and moist. The rainfall in Anderson County averages 41.70 inches per year, compared to the Texas average of 21.0 inches per year. Over 980 plant species have been documented on the property, but the vegetation within the project area consists mostly of a deciduous forest overstory of oak, hickory, elm, and sweet gum trees (TPWD 2005). Understory species include huckleberry, dogwood, American beautyberry, yaupon, hawthorn, and green-brier (TPWD 2005). The forest floor consists of various grasses and forbs and abundant poison ivy.

The soils in this area are mostly yellowish brown, rapidly permeable loamy sands on the uplands, and fairly permeable, gray brown loamy sands in the bottomlands. Based on observation of several cut-banks along the eastern project boundary, the sandy deposits reach on average about $120 \mathrm{~cm}$ above the dark red clay deposits (Figure 2-2). The vast majority of shovel tests excavated by CAR exhibit yellowish brown Queen City sand, and the underlying red clays were never breached at anytime during the survey. 


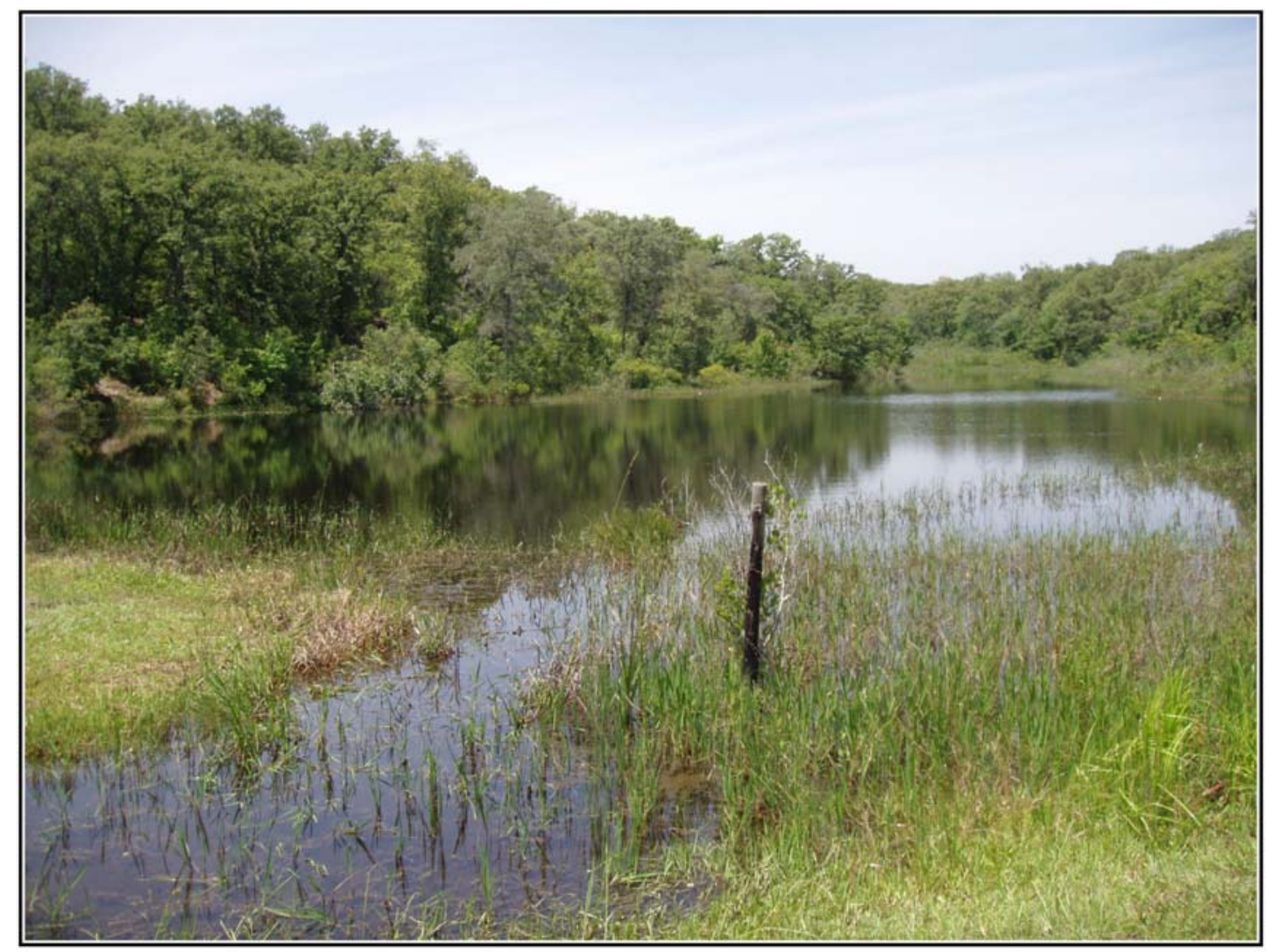

Figure 2-1. Wetland habitat in northeast portion of project area.

The project area's soils are mostly of Queen City Sand, an Eocene-aged formation (Barnes 1967). It is a fine-grained quartz that is light-gray to yellowish orange. Soils closer to Catfish Creek in this area are Quaternary Alluvium deposits that are more recent and quickly formed. Unconsolidated sands have been shown to make up an elaborate mantle across large parts of East Texas uplands. Fields (1995) has suggested that some middle to late Holocene deposits in East Texas may have been shifted or removed from the archaeological record by erosive forces and landscape instability. In several cases, these deposits of upland sands have revealed mixtures of Holocene colluvial and eolian deposits containing a great deal of site integrity in the archaeological record (Fields and Heinrich 1987, Heinrich 1986). It has long been held that future studies in the East Texas sand mantle will require solid geoarchaeological investigations to understand the dynamic nature of deposition in this area more accurately (Perttula et al. 1986: 236). Recently, geoarchaeological studies and OSL dating have demonstrated that in situ archaeological sites do exist in this region (Frederick et al. 2002:214). 


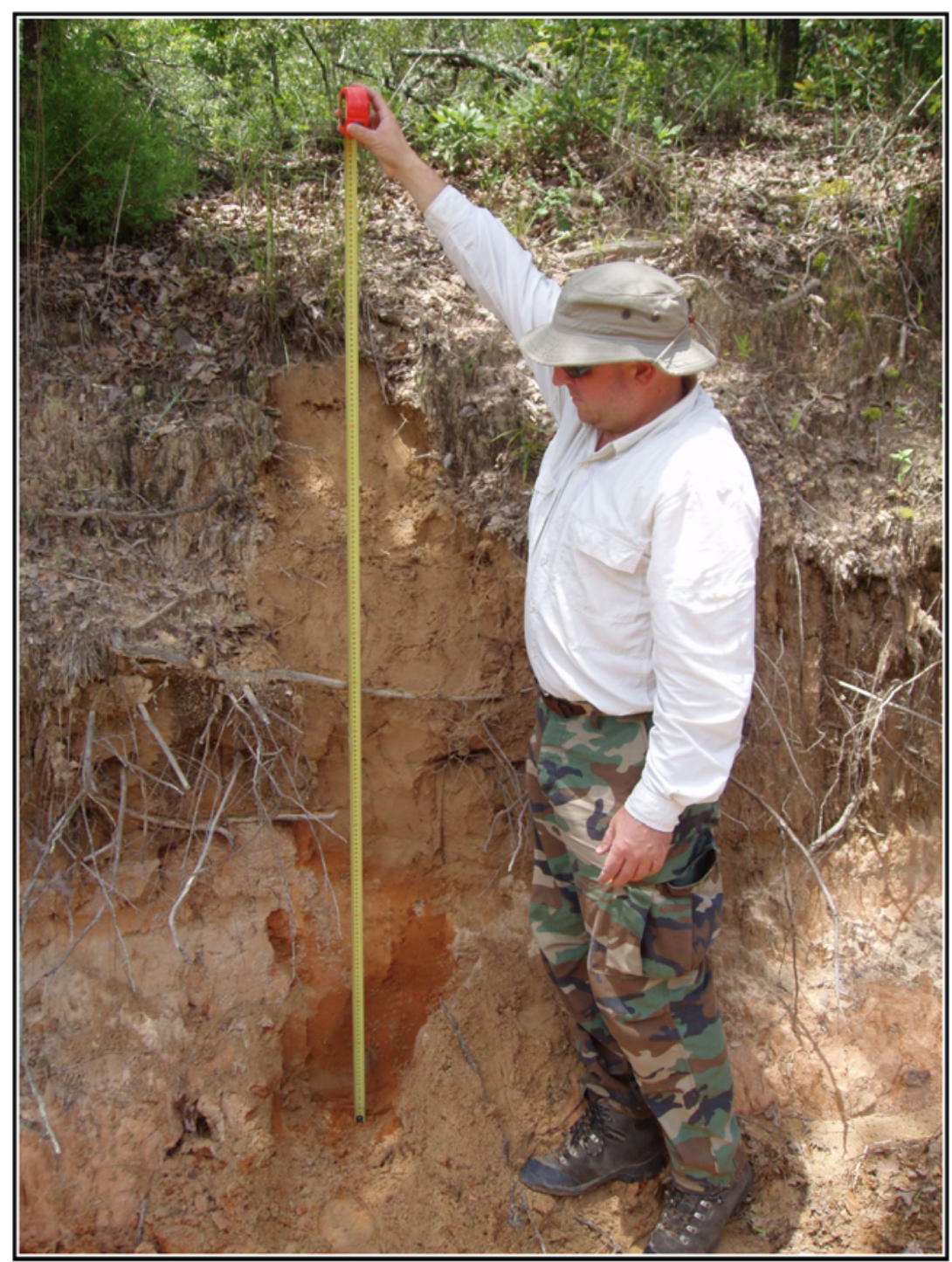

Figure 2-2. Cut- bank revealing $120 \mathrm{~cm}$ Of sandy soil above red clay. 


\section{Chapter 3: Archaeological and Historical Background}

Few major archaeological investigations have been carried out in Anderson County in the past 60 years. A.T. Jackson conducted extensive excavations at the A.C. Saunders site (Jackson 1936) in the northeast corner of the county. Investigations also took place at the Pace McDonald site north of Palestine, but went largely unpublished (Thurmond 1978). At the time of its publication, the Archaeological Bibliography for the Northeastern Region of Texas cited 50 references for Anderson County, but many of these endeavors were small scale surveys that covered limited project areas (Martin 1990). Major Reservoir projects in this county include Palestine Reservoir (Anderson et al. 1974), Tennessee Colony Lake (Richner 1977; Richner and Lee 1976, 1977), Trinity River Basin (Richner and Bagot 1978), and the Trinity River Multiple Use Project (Sorrow 1973). They offered slightly more comprehensive views of prehistoric populations in this area.

Prehistoric occupations in this region run the gamut from Paleoindian through Historic Caddoan, from 9500 B.C. to the 1860s (Kenmotsu and Pertulla 1993). Meltzer and Bever (1995:Table 1) recovered a single Clovis Point from Anderson County. In the Story et al. (1990) overview of the region, they report Dalton and Scotsbluff points from the county. Although pre-Late Archaic deposits are not well documented, Archaic occupations have been recorded from survey and excavation efforts at Lake Palestine (Anderson 1973; Anderson et al. 1974; Skinner 1971). These hunting sites were predominantly associated with "streamside locations near relatively fertile soils” (Anderson 1971:iii).

Many Late Prehistoric populations in Anderson County were primarily Caddoan speaking groups who resided in settled communities in the Neches River drainage basin towards the east. These groups sometimes left behind middens, small cemeteries, and pottery vessels of exceptional quality (Richner 1982:206). Early Ceramic sites represented in part by Williams Plain pottery, are virtually absent from this area. Late Caddoan sites are slightly better known, as Anderson County is on the periphery of the Mossy Grove region (Story et al. 1990). The Early Caddoan (A.D. 8001400) occupation, as documented by Keller (1975), represents the cultivation of maize in certain

floodplains complimented by the hunting and gathering of native plants and animals. The Late Caddoan occupation (A.D. 1400-1700) exhibits similar subsistence patterns. Many Late Caddoan 
sites have been recorded along the Catfish Creek drainage which skirts the project area (Richner 1982). Looting of archaeological sites in East Texas is common, however, and undisturbed Caddoan sites become more and more scarce.

No prior archaeological surveys have been conducted in this specific part of the GEWMA, and no prehistoric sites are known to be present in the project area. Within the Gus Engeling Wildlife Management Area on the whole, only a few archaeological surveys and testing projects have been conducted. Several formal surveys in 1987 and 1988 took place along select plots of the floodplain of Catfish Creek and in an upland area just to the east that revealed 8 archaeological sites (Davis 1988). They include 6 prehistoric sites (41AN85, and 41AN133-137), and two nineteenth to twentieth century homestead sites (41AN138, 41AN139). 41AN133 includes a large lithic scatter on a Holocene age terrace remnant west of Catfish Creek. All eight were formally designated as State Archaeological Landmark properties (Godwin 1988). None of these sites to date, have yet been tested for National Register of Historic Places eligibility. The development of a wetland area led to limited archaeological testing of site 41AN85. This endeavor involved a single backhoe trench and several 1 x $1 \mathrm{~m}$ units and 0.5 x $0.5 \mathrm{~m}$ units. Diagnostics recovered consisted of several Steiner, Dawson, and Gary projectile points, as well as grit-grog-bone tempered prehistoric pottery indicating Middle Archaic to Late Prehistoric occupations (Drake 1995). Also, a survey within 4 former share cropped fields and proposed borrow sites was conducted, but yielded no archaeological sites (Corbin 1992a, 1992b).

Scans of aerial photographs of the project area were provided to CAR by TPWD. The photographs were taken in the 1940's and the 1960's. Based on analysis of these low resolution images, no historic structures were erected on the project area. A few hunting blinds were noted during survey, but were expediently assembled with noticeably modern, scarcely weathered materials and were not documented.

A brief history of Anderson County could be dated back to early 1835, when two settlers, Joseph Jordan and William Ewing, bought land two miles southeast of present day Palestine in an area now known as the John H. Reagan home site East Texas Genealogical Society (ETGS 2007). A settlement called Houston was started there, and by order of Gen. Sam Houston, a fort was built in the public square in his name. After Texas won its independence and eventually joined the United States, the economic foundation of Anderson County remained primarily agriculture with cotton production as the dominant trade well beyond the Civil War. The 1870 census showed a population of 9,229 people in Anderson County (ETGS 2007). During the next ten years the 
population almost doubled, due mainly to the arrival of railroad lines into the county. The International, the first railroad to come to Anderson County, reached Palestine on July 11, 1872. By the time of the 1880 census, the population of Palestine had doubled to 17,395 (ETGS 2007).

The agricultural settlements of Anderson County are well documented. In 1900, total farmland acreage was 368,136. By 1950, this figure had escalated to 487,505 acres (UVL 2007). Only 206 farms existed in this region in 1850, but by 1950 there were 2,864 farms (UVL 2007). Agricultural production dominated the economy of Anderson County from 1880 to 1940, but oil resources were found in the county in 1881. In 1902, the first rotary rig was shipped to the county but the first productive oil well was not produced until 1928. The discovery helped lessen the severity of the Great Depression on the county. 


\section{Chapter 4: Survey Methodology}

The objectives of the Center for Archaeological Research were to locate, identify, and delineate prehistoric and historic archaeological sites (including buildings and structures more than 50 years old) and to ascertain the context, depth, extent and artifact content of encountered sites. The specific areas within the project area that are to be impacted by future log preparation and hauling efforts consist of two long corridors along existing roads on the north and south project area boundaries, 58 staging areas, and 17 new road segments (Figure 4-1). These areas were systematically investigated through pedestrian survey accompanied by shovel testing. A reconnaissance survey of the remaining project area, while accessing the targeted specific survey areas, also took place in case of a need to reposition staging areas due to the presence of possible archaeological sites. Thus, the primary goals were to document and record any sites, prehistoric and historic, and provide alternative routes more conducive to impact avoidance should archaeological sites exist in specific survey areas.

To accomplish these goals, field investigations consisted of shovel testing in specific survey areas targeted for restoration activities, and reconnaissance survey within the remainder of the project area. Before CAR initiated the survey, Wes Littrell of TPWD directed a road crew that flagged the routes of the specific survey areas to be impacted by future restoration activities with orange flagging, using a recreational GPS unit, and steel tape. As field conditions and the topography of the landscape influenced the placement of staging areas and new roads, certain proposed corridors and staging areas present in the original project plans were shortened, displaced, or removed from consideration. Originally, the north corridor measured $4.05 \mathrm{~km}$ and the south corridor measured $1.15 \mathrm{~km}$. When TPWD staff and flagging crews encountered slopes and drainages of varying degrees, the original north and south corridors portions were reduced to $1,800 \mathrm{~m}$ and $700 \mathrm{~m}$, respectively because of their proximity to drainages and the adverse affect of moving mechanical equipment onto sloping terrain. For this reason, two of the original 60 staging areas, arbitrarily designated by CAR as SA18 and SA43, were eliminated from proposed logging activities by TPWD as well. Finally, staging area 47 and 48 were repositioned next to one another for the same reason.

The existing roads, new roads, and staging areas required distinct field strategies. The $20 \mathrm{~m}$ wide corridors along the north and south boundaries of the project area each required two parallel transects of shovel tests within $20 \mathrm{~m}$ of the asphalt roads that skirted these two boundaries. 


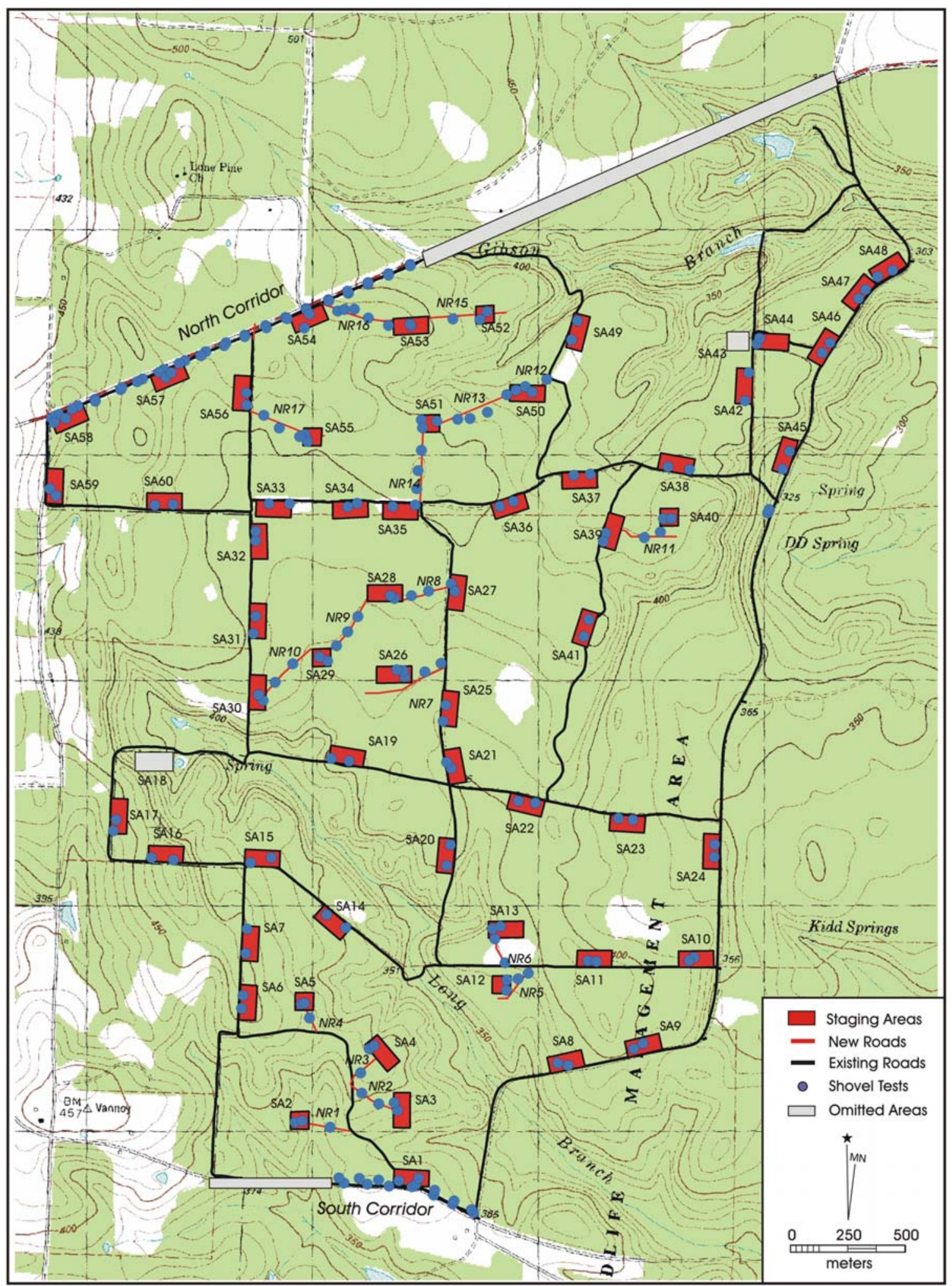

Figure 4-1. Project area shovel tests along $N$. and S. corridors, new roads, and staging areas. 
Shovel tests were placed at $100 \mathrm{~m}$ intervals along both transects. Spacing was accomplished by means of pacing and compass navigation. Requirements called for 32 shovel tests per mile (1,609 meters) along the north and south corridors. With two transects running the length of the corridors and shovel tests spaced equidistantly at $100 \mathrm{~m}$ intervals along each transect, requirements were met. Along the north corridor 37 shovel tests were excavated, and along the south corridor 14 shovel tests were excavated.

Seventeen new road segments that connected staging areas to existing roads or other staging areas also were tested at 100 -meter intervals. New roads were roughly $6 \mathrm{~m}$ in width. Some staging area/new road alignments ran for great distances and trails had to be cut through dense brush and marked with additional flagging tape. Forty-one shovel tests were excavated at $100 \mathrm{~m}$ intervals along the 17 new road segments of various lengths that total more than 4,000 m.

A total of 58 staging areas that formed semi-rectangular or square shapes each received two shovel tests as was proposed by CAR in the scope of work. Approximately 116 shovel tests were excavated to provide coverage to all 58 staging areas.

Shovel tests were roughly $35 \mathrm{~cm}$ in diameter and were excavated in $20 \mathrm{~cm}$ intervals to a terminal depth of $80 \mathrm{~cm}$. This terminal depth was established because planned restoration activities are unlikely to impact the landscape beyond $80 \mathrm{~cm}$, and the project area is not considered to be high probability. All fill was screened through $1 / 4$ inch mesh hardware cloth. CAR crew completed forms documenting the results of each shovel test, including the thickness of sediments defined by changes in texture, and/or color and the occurrence of ecofacts and artifacts from each excavated level.

For the purposes of this survey, an archaeological site had to contain a certain number of cultural materials or features older than 50 years within a given area. The definition of a site is: (1) five or more surface artifacts within a 15-meter radius (ca. $706.9 \mathrm{~m} \mathrm{sq}$.), or (2) a single cultural feature, such as a hearth, observed on the surface or exposed in shovel testing, or (3) a positive shovel test containing at least three artifacts within a given 10-cm level, or (4) a positive shovel test containing at least five total artifacts, or (5) two positive shovel tests located within 30 meters of each other.

Sub-meter accuracy GPS data was captured for each shovel test location. For the sake of clarity, two corners of each staging area also were recorded to increase the accuracy of existing project area maps. Boundaries, shovel tests, and datum associated with the lone documented site also 
were recorded and plotted. Field records for the survey were kept in a standard format and consist of quad maps, shovel test locations, the P.A.'s daily journal, shovel test forms, and photo logs. The recorded site was photographed and sketch maps and site forms were completed. 


\section{Chapter 5: Results of Investigations}

This project area required a total of 210 shovel tests. The north and south corridors received 37 and 14 shovel tests respectively. Forty-one shovel tests were spaced out along 17 new road segments, and the 58 staging areas called for 116 shovel tests. Two shovel tests also were excavated within the historic site that was recorded (41AN181). All shovel tests yielded negative results, and no prehistoric cultural material was encountered on the GEWMA landscape.

\section{SITE 41AN181}

One archaeological site was recorded during the survey of the project area. 41AN181 is a historic site and consists of the remains of a corral. The site is situated in the northeast part of the project area along the margin of the sandy terraces, off a main road (Figure 5-1). It lies over $100 \mathrm{~m}$ from the nearest staging area boundary within a zone excluded from the savannah restoration project. Site 41AN181 consists of two square holding pens bisected by a chute with multiple access gates. The site measures $40 \mathrm{~m}(\mathrm{~N}-\mathrm{S})$ by $14 \mathrm{~m}(\mathrm{E}-\mathrm{W})$ based on location of fence positions and the lack of artifacts outside these boundaries. A shovel test was placed in each of the two main holding areas, but no cultural material was encountered (Figure 5-2). GPS coordinates for both shovel tests and the site's boundaries were captured. Cultural features at the site consisted of segments of fenceline constructed from 4-inch diameter lumber posts supporting machine woven wire (Figures 5-3 and 5-4). Thirteen aluminum gate entries are located in key positions around the site, and no maker's mark was noted. The corral was assembled with modern looking machine-made wire nails with hatch marks, but two cut nails were observed on the ground along the center of the eastern fence-line of 41AN181. The remains of a ferrous metal bucket were encountered in the southern holding pen. No outbuildings or standing structures were present. No diagnostic artifacts were encountered to provide insights as to the construction time of the corral.

Two aerial photographs of the project area were examined to provide more insight about the site. One of the aerials was taken during the 1940's and the other was taken during the 1960's. The scans of these aerials were low resolution and pixilated, but they did reveal some small changes in the landscape over time. Neither of the photographs illustrate any kind of clearing at the site's location, suggesting 41AN181 came to be after the 1960's aerial was taken. Also, a fence-line existed in the 1940's running north/south, about 100 m west of where the corral would be placed. This fence-line proceeds north and stops when it hits a tributary of Gibson Branch. By the 1960's, 
that fence-line was widened into a low-grade road or fence-line clearing that intersected with a perpendicular east/west fence-line clearing connecting to the 41AN181's location. These lowgrade roads or fence-line clearings have since been overgrown, and only segments of the actual fence-line still exist. Due to the dearth of standing, intact structures and the minute quantity of artifacts present, very little can be gleaned from the archaeological record at this site.

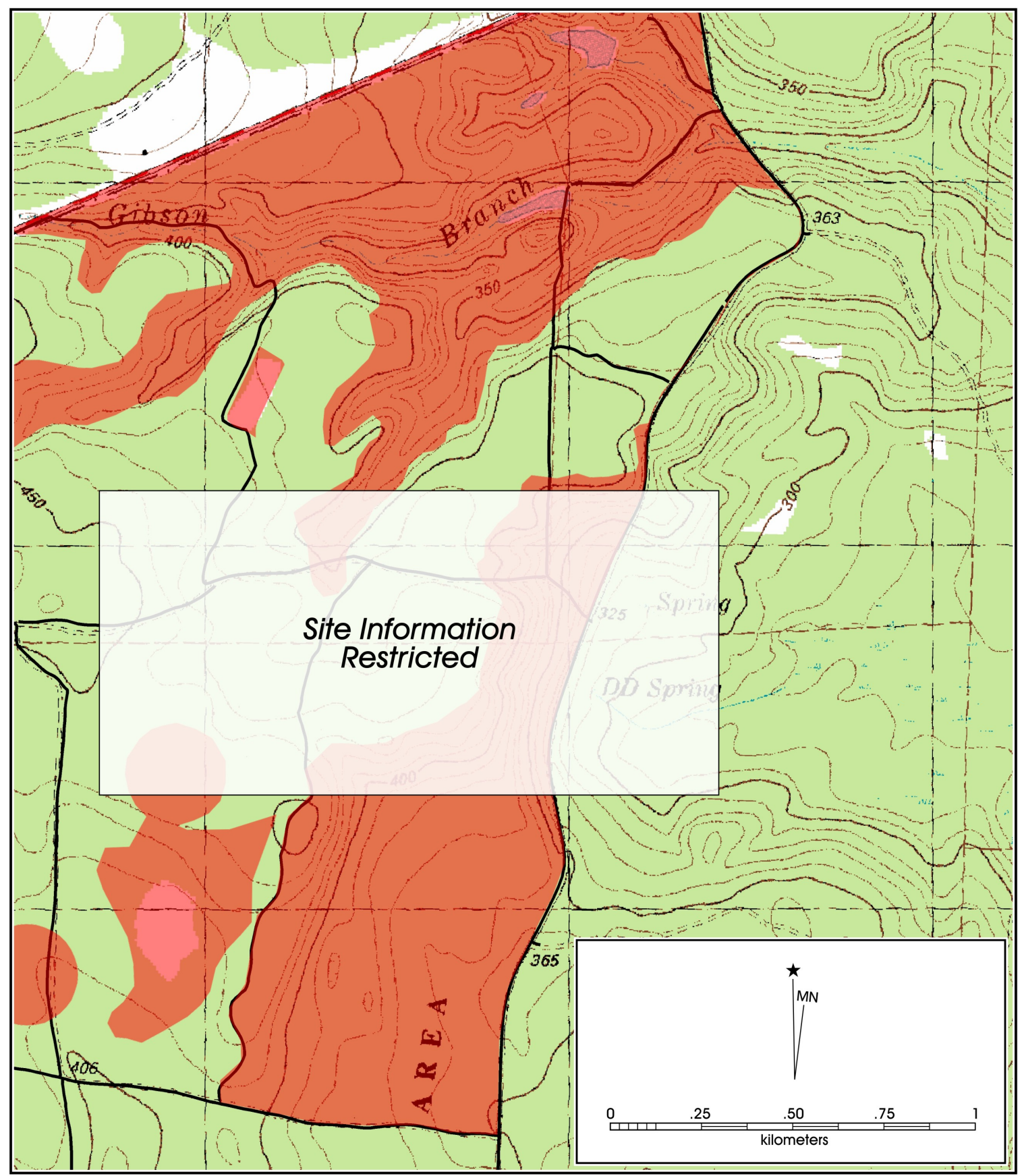

Figure 5-1. Location of 41 AN181 at Gus Engeling Wildlife Management Area on Cayuga, Tex., 7.5 minute quadrangle map. 


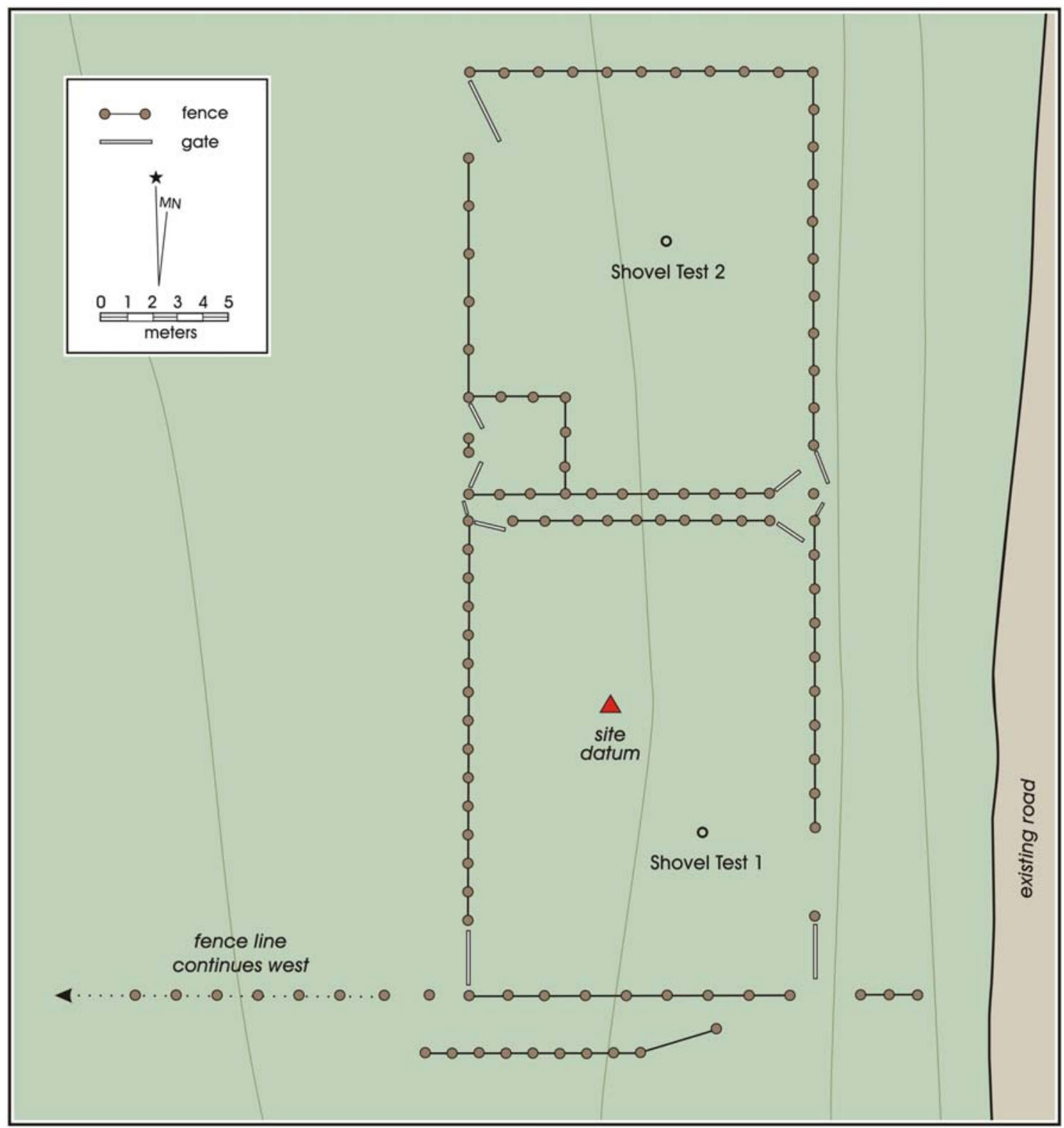

Figure 5-2. Historic corral site (41AN181). 


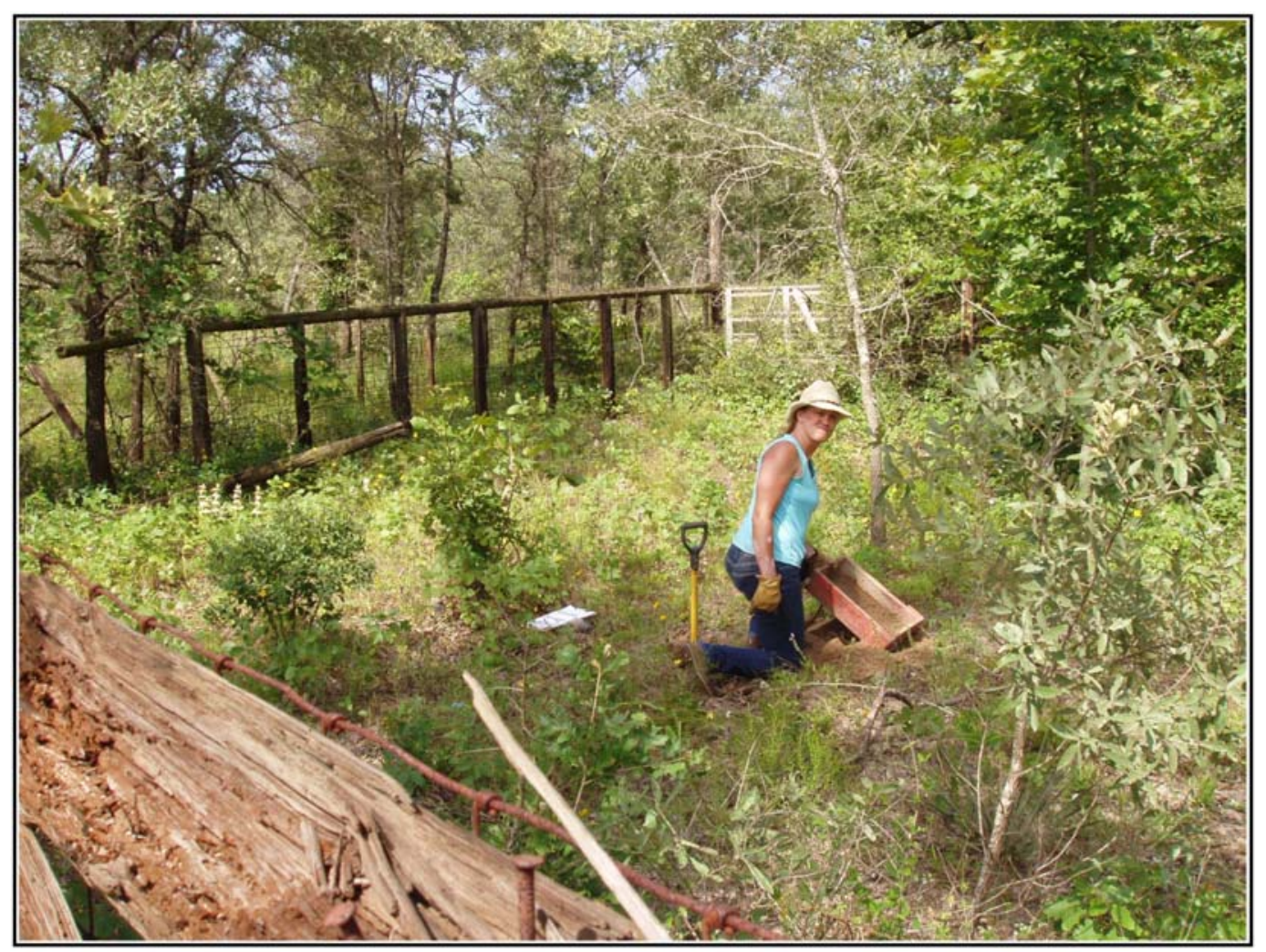

Figure 5-3. CAR crew shovel testing historic corral.

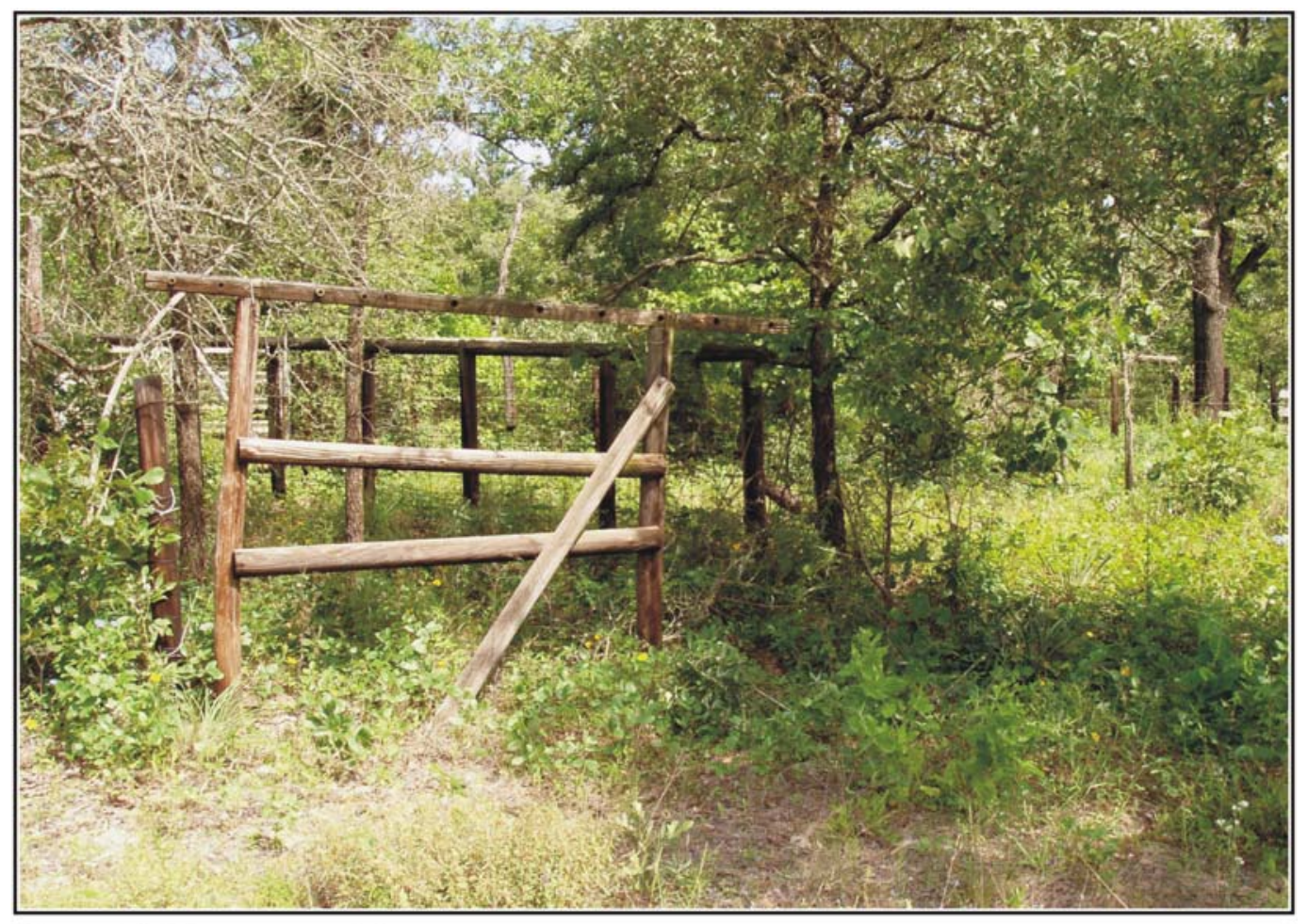

Figure 5-4. Historic corral fence segment. 


\section{Chapter 6: Summary and Recommendations}

The archaeological survey of the 2,800 acre parcel of the Post-Oak Savannah Restoration Project area within the northwest quadrant of the Gus Engeling Wildlife Management Area in Anderson County, Texas required 210 shovel tests to ascertain the extent of cultural materials in 152 acres of specific areas where restoration activities are to take place. Originally, a $4.05 \mathrm{~km}$ northern corridor and a $1.15 \mathrm{~km}$ corridor, 17 new road segments, and 60 staging areas were designated to facilitate restoration activities. Due to the presence of drainage slopes on the terrain, areas targeted for survey were reduced to a $1,800 \mathrm{~m}$ northern corridor and a $700 \mathrm{~m}$ southern corridor, 17 new road segments, and 58 staging areas. University of Texas San Antonio Center for Archaeological Research personnel excavated 37 shovel tests along the northern corridor, and 14 along the southern corridor at $100 \mathrm{~m}$ intervals. Seventeen new road segments required 41 shovel tests, and the 58 staging areas received a total of 116, also at $100 \mathrm{~m}$ intervals. A historic site was recorded during survey that required two shovel tests.

Shovel testing and pedestrian survey did not reveal any prehistoric cultural material within the project area that consisted mostly of sandy upland terraces. Since water sources are constant yearround on the project area (TPWD 2005), explanations concerning the lack of cultural material could lean toward a lack of raw lithic materials and the character of the landscape. There were no lithic outcroppings, upland gravel veneers, or knappable materials of any kind noted during survey. Major lithic resources around Anderson County would be Yegua Gravels, Uvalde Gravels and Pisgah Ridge materials (Figure 6-1). Some isolated specimens of unmodified petrified wood were encountered, which have been known to be used as a raw material for point manufacture in East Texas, were observed, but only in very scarce quantities. Addressing lithic raw material procurement is important when determining why some areas show signs of occupation and why some do not. Perttula saw variability in locally available materials

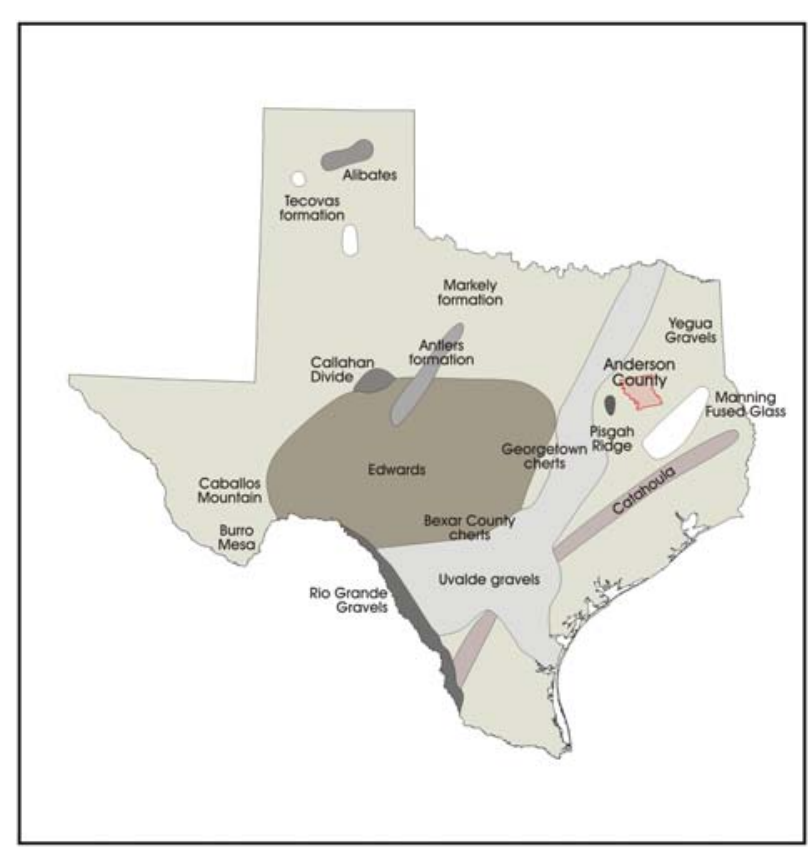

Figure 6-1. Lithic resources in Texas showing approximate locations (after Turner and Hester 1999). 
in Northeast Texas as possible indicators of changes in mobility, territory size, and interregional exchange (1984). Similar studies have indicated that group mobility decreased in Northeast Texas during the Archaic, Early Ceramic, and Late Prehistoric periods in certain areas of the Trinity River basin (McGregor (1987). Areas adjacent to the GEWMA project area with sandy knolls containing thin aprons of knappable gravels like those at Jewett Mine (S. Tomka, personal communication, July 9, 2007), might make more attractive habitation sites when mobility patterns are low, but no such deposits were encountered during this survey. Also, the project area landscape resembled mostly alluvial terraces and upland landforms, rather than low terrace remnants and floodplain rises which have been demonstrated to yield more signs of ancient human occupation in this region (Richner 1982).

The map generated as a result of this survey will assist in the management of impact avoidance in this project area totaling approximately 152 acres within the 2,800 acre project area (Figure 4-1). Since no sites were discovered in the immediate proximity of proposed roads or staging areas, there was no need to survey adjacent routes or alternate staging areas. Original staging locations for restoration activities may remain as viable points of departure for refurbishment plans.

As a result of the pedestrian survey observations and negative shovel test data of the proposed 2,800 acre Post-Oak Savannah Restoration Project at Gus Engeling Wildlife Management Area, it is our opinion that the single historic archaeological site recorded does not contribute to a better understanding of the history of Northeast Texas. Nor does it merit formal designation as a State Archaeological Landmark or warrant further archaeological work. The savannah restoration project will have no affect on the site. We recommend clearance be provided for the commencement of restoration activities in this quadrant of the GEWMA property. 


\section{References Cited}

Anderson, Keith M.

1971 Archaeological Resources of Lake Palestine, Texas. Bulletin of the Texas Archeological Society 43:121-197.

1973 Prehistoric Settlement of the Upper Neches River. Bulletin of the Texas Archaeological Society 43:121-197.

Anderson, Keith M., Kathleen Gilmore, Olin F. McCormick, III, and E. Peirre Morenon

1974 Archaeological Investigations at Lake Palestine Texas. Southern Methodist University, Institute for the Study of Earth and Man, Department of Anthropology, Contributions in Anthropology Number 11.

Barnes, Virgil E.

1967 Geological Atlas of Texas, Palestine Sheet. Bureau of Economic Geology, The University of Texas at Austin

Corbin, James

1992a Archaeological Survey of Four Share Crop Fields in the Engeling Wildlife Management Area, Anderson County, Texas. Archaeological Survey Report 92-11 (TAC permit 1092).

1992b Archaeological Survey of a Proposed Borrow Pit and Fenceline Replacement Project in the Engeling Wildlife Management Area, Anderson County, Texas. Archaeological Survey Report 92-11 (TAC permit 1112).

Davis, Michael

1988 Cultural Resource Survey and Assessment of Portions of the Gus Engeling Wildlife Management Area, Anderson County, Texas. Texas Parks and Wildlife Department Historical Sites and Restoration Branch, Austin.

Drake, Doug

1995 Limited Test Excavations at 41AN85, Engeling Wildlife Management Area, Anderson County, Texas. Texas Parks and Wildlife Department Cultural Resource Program Report 95-2, Austin, Texas.

East Texas Genealogical Society (ETGS)

Anderson County Texas History. n. pag. Online. Internet. June 18, 2007. Available: http://www.rootsweb.com/ txanders/history.html.

Fields, R.C.

1995 The Archaeology of the Post Oak Savannah of East Central Texas. Bulletin of the Texas Archaeological Society, 66, 301-331.

Fields, R.C., and Heinrich, P.V.

1987 Geoarchaeology of the Alley Road site, 41LN149B. In R.C. Fields (Ed.), Excavations at at the Alley Road site (41LN149B) and the Harris Hole site (41LN30), Jewett Mine Project, Leon County, Texas (pp.64-88), Reports of Investigations No. 61. Austin, TX: Prewitt and Associates, Inc. 
Frederick, Charles D., Mark D. Bateman, and Robert Rogers

2002 Evidence for Eolian Deposition in the Sandy Uplands of East Texas and the Implications for Archaeological Site Integrity. Geoarchaeology: An International Journal, 17(2):191217.

Godwin, Molly

1988 Letter from SHPO dated November 1988 stating that Sites 41AN85, and 41AN133 through 41AN139 have been accepted as SAL listed properties.

Heinrich, P.V.

1986 Geomorphology of seven sites at the Jewett Mine Project. In R.C. Fields, S.V. Lisk, J.M. Jackson, M.D. Freeman, and G.L. Bailey (Eds.), National Register assessments of archaeological and historical resources at the Jewitt Mine, Leon County, Texas, Appendix A (pp. 191-223), Reports of Investigations No. 48. Austin, TX: Prewitt and Associates, Inc.

Jackson, A.T.

1936 A 'Perpetual Fire' Site. Bulletin of the Texas Archaeological and Paleontological Society 8:134-173.

Keller, John E.

1975 Paleoecological Considerations and East Texas Archaeology. Bulletin of the Texas Archaeological Society 46:243-248.

Kentmotsu, Nancy Adele, and Timothy K. Pertulla

1993 Archeology in the Eastern Planning Region, Texas: A Planning Document. Department of Antiquities Protection, Cultural Resources Management Report 3. Texas Historical Commission.

Martin, William A.

1990 Archaeological Bibliography for the Northeastern Region of Texas. Department of Planning and Review, Cultural Resource Management Report 1 and Office of the State Archaeologist Special Report 32.

McGregor, D.E.

1987 Lithic Raw Material Utilization. In Hunter-Gatherer Adaptations along the Prairie Margin: Site Excavations and Synthesis of Prehistoric Archaeology, edited by D.E. McGregor and J.E. Bruseth, pp. 185-196. Richland Creek Technical Series, vol. III. Archaeology Research Program, Southern Methodist University, Dallas.

Meltzer, David J., and Michael R. Bever

1995 Paleoindians of Texas: An Update on the Texas Clovis Fluted Point Technology. Bulletin of the Texas Archaeological Society 66: 47-81.

Perttula, T.K.

1984 Patterns of Prehistoric Lithic Raw Material Utilization in the Caddoan Area: The Western Gulf Coastal Plain. In Prehistoric Chert Exploitation: Studies from the Midcontinent, edited by B.M. Butler and E.E. May, pp.129-148. Occasional Paper No. 2, Center for Archaeological Investigations, Southern Illinois University at Carbondale. 
Perttula, T.K., B.D. Skiles, M.B. Collins, M.C. Trachte, and F. Valdez, Jr.

1986 This Everlasting Sand Bed: Cultural Resources Investigations at the Texas Big Sandy Project, Wood and Upshur Counties, Texas. Report of Investigations, Number 52. Prewitt and Associates, Austin.

Richner, Jeffrey J.

1977 Archeological and Ethnohistorical Survey at Tennessee Colony Lake. Archaeology Research Program, Southern Methodist University. Dallas.

1982 Tennessee Colony III. Archaeology Research Program, Southern Methodist University, Dallas.

Richner, Jeffrey J., and Joe T. Bagot (Assemblers)

1978 A Reconnaissance Survey of the Trinity River Basin, 1976-1977. Archaeology Research Program, Southern Methodist University Research Report 113.

Richner, Jeffrey J., and Reed Lee

1976 Cultural Resources at Tennessee Colony Lake. Archaeology Research Program, Southern Methodist University.

1977 Archaeological and Ethnohistorical Survey at Tennessee Colony Lake, 1975. Archaeology Research Program, Southern Methodist University.

Skinner, S. Alan

1971 Historical Archeology of the Neches Saline, Smith County, Texas. Texas Historical Committee, Archeological Report Number 21.

Sorrow, William M.

1973 Preliminary Archaeological Reconnaissance of the Selected Area to be affected by the Trinity River Multiple Purpose Project, Texas. Texas Archaeological Salvage Project, Research Report 17. The University of Texas at Austin.

Story, Dee Ann, Janice A. Guy, Barbara A. Burnett. Marthy Doty Freeman, Jerome C. Rose, D. Gentry Steele, Ben W. Olive, and Karl G. Reinhard

1990 The Archeology and Bioarcheology of the Gulf Coastal Plain. Arkansas Survey, Research Series Number 38. Fayetteville.

Texas Parks and Wildlife Department

2005 Gus Engeling Wildlife Management Area. Brochure available from the Texas State Publications Clearinghouse.

Thurmond, J. Peter

1978 Pace McDonald Site: A Caddoan Mound Center in Anderson County,Texas. Unpublished manuscript on file at the Texas Archaeological Research Laboratory in Austin, Texas.

Turner, E.S., and T.R. Hester

1993 A Field Guide to Stone artifacts of Texas Indians. Texas Monthly Field Guide Series. Second Edition. Gulf Publishing Company, Houston.

University of Virginia Library (UVL)

Geostat Center. n. pag. Online. Internet. July 9, 2007. Available:

http://fisher.lib.virginia.edu/collections/stats/histcensus/. 